\title{
DIRECTIONS OF IMPROVEMENT OF STATE ANTI-CRISIS REGULATION SYSTEM IN UKRAINE
}

\section{НАПРЯМИ ВДОСКОНАЛЕННЯ СИСТЕМИ ДЕРЖАВНОГО АНТИКРИЗОВОГО РЕГУЛЮВАННЯ В УКРАЇНІ}

UDC 330.33.01:338.246.02

DOI: https://doi.org/10.32843/infrastruct49-8

\section{Kis Halyna}

Candidate of Economic Sciences,

Associate Professor,

Senior Lecturer at Department of

Management and Administration

Ivano-Frankivsk National Technical

University of Oil and Gas

Haliuk Iryna

Candidate of Economic Sciences, Associate Professor,

Senior Lecturer at Department of Management and Administration Ivano-Frankivsk National Technical University of Oil and Gas

\begin{abstract}
The article offers theoretical and methodologi$\mathrm{cal}$ approaches and provides practical recommendations for improving state anti-crisis management system in Ukraine using the experience of South Korea and Japan. Integrating the experience of these countries and taking into account trends in the world economy, the main directions of the state anti-crisis program, which should be developed and implemented in Ukraine are defined: development and implementation of the doctrine of catching up; giving priority to the development of labor-intensive industries; assistance in obtaining foreign direct investment; restructuring of national financial institutions; liberalization of the foreign economic sphere; stimulating nature of the budget for the general development of the economy; implementation of administrative and financial reform in Ukraine; implementation of effective industrial policy; continuity in the history of socio-economic relations; introduction of a "soft" subsystem for managing economic processes. Key words: anti-crisis management, state regulation of economy, crisis-free development.
\end{abstract}

B статье предложены теоретико-методологические подходы и даны практические рекомендации по совершенствованию системы государственного антикризисного регулирования в Украине с использованием опыта Южной Кореи и Японии. Интегрируя опыт этих стран и учитывая тенденции в мировой экономике, выделены основные направления государственной антикризисной программы, которая должна быть разработана и внедрена в Украине: разработка и внедрение доктрины догоняющего экономического развития; предоставление приоритетности развития трудоемких отраслей; содействие в получении прямых иностранных инвестиций; реструктуризация национальных фьинансовых институтов; либерализация внешнеэкономической сореры; стимулирующий характер бюджета для общего развития экономики; осуществления административно-фринансовой реформы в Украине; реализация эфффективной промышленной политики; преемственность в истории развития социально-экономических отношений; внедрение "мягкой" подсистемы управления экономическими процессами.

Ключевые слова: антикризисное управление, государственное регулирование экономики, бескризисное развитие.

В статті запропоновано теоретико-методологічних підходи та надано практичні рекомендації щодо вдосконалення системи державного антикризового регулювання в Україні з використанням досвіду Південної Кореї та Японії. Встановлено, що застосовувана в Південній Кореї система антикризових заходів включає реформу сектору фрінансово-промислових груп, трансформацію ринку праці, реструктуризацію національних фрінансових інститутів та лібералізацію зовнішньоекономічної сфери. Зроблено висновок, що висока інтенсивність праці та успішне поєднання регулюючої ролі держави та інтересів найбільших південнокорейських конгломератів (чеболів) були запорукою економічного зростання в цій країні. Перманентне впровадження заходів щодо захисту інвестицій та підвищення інвестиційної привабливості компаній, зокрема через усунення бюрократичних перешкод та полегшення процедури розміщення капіталу, сприяють економічному зростанню Південної Кореї. Акцентовано увагу на ключовій ролі уряду при проведенні оздоровчих заходів в Південній Кореї та рекомендовано дотримуватися цього підходу і у вітчизняній економіці. Визначено, що основою безкризового розвитку Японії є запровадження та надання пріоритетності так званій "м'якій" підсистемі управління, яка фуункціонує поряд із "жорсткою" як на рівні держави, так і на рівні окремих суб'єктів господарювання, а також перманентно здійснювана адміністративно-фрінансова реформ та промислова політика, яка концентрується на перерозподілі ресурсів між галузями або зміні організаційно-підприємницької структури тієї чи іншої галузі з метою посилення економічної могутності країни. Інтегруючи досвід Південної Кореї і Японії, враховуючи наведені тенденції у світовій економіці та вимоги інноваційної стратегії розвитку, виділено основні напрями державної антикризової програми, яка повинна бути розроблена та впроваджена в Україні та яка уможливлює побудову ефективної економічної системи: розробка та впровадження доктрини наздоганяючого економічного розвитку; надання пріоритетності розвитку трудомістких галузей; сприяння в отриманні прямих іноземних інвестицій; реструктуризація національних фрінансових інститутів; лібералізація зовнішньоекономічної ссрери; стимулюючий характер бюджету для загального розвитку економіки; здійснення адміністративно-фрінансової реформи в Україні; реалізація ефективної промислової політики; спадкоємність в історії розвитку соціально-економічних відносин; впровадження "м'якої" підсистеми управління економічними процесами.

Ключові слова: антикризове управління, державне регулювання економіки, безкризовий розвиток.

Introduction. The need to improve the system of state regulation at the present stage is due to the fact that the current economic policy in Ukraine and its tools are not aimed at ensuring quality transformations in the economic life of society - innovative development, renewal of production, overcoming deep income differentiation. Within the framework of such a model of development that exists in our country today, radical modernization of the economy is impossible. It is necessary to move to an institutional model of market transformations, which must be combined with elements of state regulation.

State anti-crisis regulation is a macroeconomic category that reflects the relations that arise in the organizational, economic and legal influence of the state to protect enterprises from crisis situations, bankruptcy prevention. It is based on the analysis of the situation and the most specific and clear goal setting, the development of tools that can transform crisis situations in the direction of solving problems [1, pp. 17-20].

To ensure the long-term competitiveness of the domestic economy, the system of selection criteria for enterprises to provide them with state support must take into account existing trends in the world economy, changes that should be expected globally [2]. When building a strategy for economic recovery and development, public authorities must take 
into account the following processes in the world economy: strengthening globalization processes and, consequently, strengthening the global monopolization of the economy (entering the free market, both external and internal, is very difficult for new or closed); replacement of the natural and physical form of goods by a virtual form of intellectual goods in the form of information or service; intellectualization of labor; undermining the monopolies of elite countries on high technology [3-5].

Thus, the traditional industrial development for Ukraine should mean a real transformation of the state into a raw material appendage of economically developed countries. We need an innovative development strategy that could ensure a technological breakthrough on a global scale. Such a breakthrough is possible at the local level of technological structures (technopolises, technoparks, free economic zones) under the condition of the most effective use of the available intellectual and technological potential [3-5]. The most powerful potential in Ukraine is preserved in the fields of aircraft construction, biotechnology, production of armored vehicles, aerospace [6, p. 65]. It is the development of these industries that is a priority, it should become a source of technological breakthrough and subsequent radical changes in the financial, economic and social spheres.

Analysis of recent research and publications. The research of the theory and practice of formation and functioning of the system of state anti-crisis regulation is devoted to the works of scientists: G. Atamanchuk, M. Bilynska, M. Haman, G. Gruba, S. Doroguntsov, D. Karamishev, V. Knyazev, V. Kozakov, S. Kravchenko, O. Loshchikhin, Yu. Mal-chyn, L. Ivashova, O. Povazhny, O. Sukhodolya, V. Tron, V. Udovychenko, A. Fedoryshchev, V. Shamray, N. Shevchenko and others. O. Valevsky, O. Kilievych, I. Rozputenko, G. Sytnyk, A. Sukhorukov, M. Frolova, V. Shary, A. Yuryna and other domestic and foreign researchers paid attention to certain problems of state regulation of crisis phenomena. According to A. Galchynsky, the use of the experience of economic transformation in Asian countries is extremely critical for Ukraine, as there are some of the most fundamental positions of economic policy, which have a common basis with the respective countries and which we have not yet implemented [7, p. 2].

Setting objectives. In view of the above, it is relevant for the Ukrainian economy to analyze foreign experience in crisis management, especially in Asian countries such as South Korea and Japan. Thus, the purpose of this article is to critically analyze the practice of state anti-crisis regulation in the above countries and assess the possibility of its implementation in Ukraine.

Research results. The experience of South Korea, which has faced economic crises three times in the last 50 years and twice in the last 10 years and has always successfully emerged from a difficult situation, can be interesting and useful. Especially useful for our country can be the study of programs based on modernization of the economy, on the simplification of doing business, on the most efficient use of available resources.

The basis of the phenomenal economic miracle in South Korea was laid in the early 60's of the twentieth century. South Korea was on the brink of poverty at the time, but the adoption of an unprecedented economic development program in 1961 and its effective implementation allowed the country to achieve extremely high results in a short historical period [8]. In our opinion, it is expedient to consider the doctrine of economic growth chosen by the government and the preconditions for such growth.

In South Korea during the period under review adopted a doctrine according to which the country is gradually moving towards technological development, following the example of countries directly ahead of them in the development process (the so-called doctrine of "flying geese", developed by the famous Japanese economist Kaname Akamatsu). This doctrine assumes that in an economy with a surplus of labor and a lack of capital (namely, the situation in South Korea in the early 1960s and in Ukraine today), labor-intensive industries are becoming competitive in the international market. As the growth of savings and the development of education create a reserve of capital and skilled labor, more capital-intensive industries and industries that require highly skilled labor are growing. Following the doctrine of "flying geese", Asian countries have achieved phenomenal success, which was called the "Asian economic miracle". The leading role in the development and implementation of strategies and tactics for the development of the South Korean economy in the 1960s - 1980s belonged to the state, which relied on large national financial-industrial groups (financial-industrial groups, in Korean - "cheboli") [8].

The extremely important role of bees is evidenced by the fact that several dozen such financial and industrial groups (eg, Samsung, Hyundai, Kia Motors, Hanbo Steel, Hyundai, LG, ES Ka Global) control almost all sectors of the economy and they own most of the major medium-sized companies [9, p. 3]. Among the factors that contributed to the dynamic development of bees, we can note: rapid development of new industries and diversification of activities; use of the latest foreign technologies; great attention to the training of managerial staff; intersectoral synergy and the ability to quickly accumulate significant financial resources for the implementation of large strategically important projects; high financial, technological and organizational stability. Thanks to the successful reform for the period from 1961 to 1996, South Korea's GDP grew from 2.1 billion to 480.2 billion US dollars, ie almost 240 times, and the value of the country's exports 
increased by 3930 times, reaching 129.7 billion US dollars in 1996 [10]. Growth based on the development of bees had its downsides, which manifested themselves in 1996-1997 in the form of bankruptcy of a number of financial-industrial groups and intensified during the Asian financial crisis of 1997-1998.

The main causes of the economic crisis during this period were: the weakness of the financial sector of South Korea and its high dependence on international capital; unreasonably high level of financial borrowings of bees and, accordingly, the negative ratio of their debts and the value of fixed assets; inefficient corporate investments made as a result of a superficial assessment of project effectiveness; issuance of doubtful loans without assessing the solvency of companies. At this stage, a system of anti-crisis measures was applied, which included the reform of the sector of financial-industrial groups, the transformation of the labor market, the restructuring of national financial institutions and the liberalization of the foreign economic sphere. Thus, the high intensity of labor and the successful combination of the regulatory role of the state and the interests of the largest South Korean conglomerates (chebols) were the key to economic growth in this country. In Ukraine, however, there is a highly skilled workforce and the scientific industries that served the production complex of the former USSR have not lost their potential. Thus, the preconditions for rapid economic growth in our country are obvious.

The experience of reforms in the corporate sector is especially important for Ukraine, as much emphasis was placed on stimulating the development of small venture enterprises in this issue along with the reform of the Chebols. Such companies are extremely mobile, are developing rapidly and are ready to end the dominance of clumsy financial and industrial groups in the Korean market.

In our opinion, it is also useful to study the experience of changing the policy of attracting investments from abroad: the emphasis is on obtaining foreign direct investment. For this purpose the Investment Services Center was established, which removed bureaucratic obstacles and facilitated the procedure of capital allocation. Measures have been introduced to protect investments, increase the investment attractiveness of companies [8]. These and other measures, as well as the favorable situation on the world market contributed to economic growth in 1999-2001.

Another downturn in South Korea began in late 2001, when after the terrorist attacks of September 11, the United States virtually lost economic interest in the country and South Korea's exports fell sharply. In addition, prices and demand for microchips, Korea's main export, have declined worldwide. Growth was replaced by a downturn again, but the government immediately began implementing a program of action to prevent the downturn. Among the measures of the state it should be noted first of all that the budget was stimulating for the general development of the economy. Implemented measures of a strategic nature included increasing attention to the professional level of companies and corporations management, stimulating intellectual property development, focusing on increasing profitability, reducing costs [8].

Characterizing the current situation in Korea, it should be noted that the country is making significant efforts to maintain economic stability, maintaining existing positions in the world economy.

Without specifying at this stage of the analysis the specific measures to be borrowed from Ukraine from the Korean experience, in our opinion, we should emphasize the extremely important role of the government in health improvement in South Korea for the entire period analyzed and recommend adherence to this approach in the domestic economy.

Analyzing the foreign experience of anti-crisis regulation of the economy, it is impossible to largely avoid the unique experience of Japan. This country, after a large-scale upheaval caused by the surrender in World War II, has experienced virtually no significant shocks. Thus, in the United States, Western Europe, the newly industrialized countries, the structural transformations of the second half of the 70's, the crisis of the 90's led to serious imbalances in economic systems, including rising inflation, declining business activity, exacerbation of labor conflicts, destabilization of the political situation. At the same time, Japan's economy has responded relatively calmly to global economic crises. This is due to the specifics of Japanese society, which implements the principles of unity and solidarity of all its members, as well as skillful policy of the state and business structures aimed at ensuring a high level of stability and limiting crises in all areas [11, p. 475].

The main advantage of the Japanese type of public relations in preventing and overcoming crises is the introduction and prioritization of the so-called "soft" management subsystem, which operates alongside the "hard" both at the state level and at the level of individual businesses.

"Hard" management subsystem at the state level includes a set of measures in the field of tax, investment and innovation, science and technology, energy policy of the government, and at the micro level - systems of automation and computerization of production, technical and technological processes and more. At the same time, the "soft" management subsystem is an original system of civil society in the field of production management support and includes certain management methods and a system of relations in the organization of production. At the macroeconomic level, the "soft" subsystem includes industrial associations, organizational forms of interaction between workers and managers, government and business. At the microeconomic level, such a management 
subsystem includes methods of decision-making by major economic agents - enterprises, as well as the order of employment, especially the dissemination of information, etc. [12, p. 49-56].

It should be noted that giving priority to the "soft" management subsystem contributes to the growth of social and intellectual potential of the population, allows to overcome at all levels the information asymmetry on the processes in the economy, in particular market trends, competitive relations, mechanisms of functioning of certain sectors of the economy, etc. This greatly helps to reduce the risk of crisis development in society [13].

As noted by V. A. Predborsky in his monograph $[11$, p. 453], very important at the present stage of development for Ukraine is the introduction of "soft" subsystem management of economic processes, as it will increase the efficiency of management of socio-economic processes, eliminate contradictions between the state and economic behavior economic entities, reducing the shadowing of economic activity, eliminating crises in the development of the economic system as a whole.

Another element of Japanese society, which largely determines its crisis-free development, is the ongoing administrative and financial reform. Its task is to develop and implement such a management system that could overcome the inertial practice of administrative and financial measures and take on new tasks that have a national and state character. Also contributes to the stability of the Japanese economy industrial policy, the essence of which is to redistribute resources between industries or change the organizational and entrepreneurial structure of an industry to strengthen the economic power of the country when the market competitive mechanism is unable to solve this problem [14, p. 31].

Borrowing the experience of Japan in the above areas, in our opinion, is not only possible but necessary: the implementation of administrative and financial reform in Ukraine, the implementation of effective industrial policy should increase economic power, reduce bureaucratic burden on the economy, stabilize economic development. It should also be noted that the main condition for stability and crisis-free development in Japan and to be ensured in Ukraine is continuity in the history of socio-economic relations: the new level of development should be based not on denial of the previous one, but on renewal and enrichment.

Conclusions. Integrating the experience of South Korea and Japan, taking into account the trends in the world economy and the requirements of innovative development strategy, we highlight the main directions of the state anti-crisis program, which should be developed and implemented in Ukraine: development and implementation of the doctrine of catching up with economic development; giving priority to the development of labor-intensive industries; assistance in obtaining foreign direct investment; restructuring of national financial institutions; liberalization of the foreign economic sphere; stimulating nature of the budget for the general development of the economy; implementation of administrative and financial reform in Ukraine; implementation of effective industrial policy; continuity in the history of socio-economic relations; introduction of a "soft" subsystem for managing economic processes.

Only the comprehensive implementation of our proposed measures makes it possible in the future to build an effective economic system, reach a new, high standard of living and Ukraine's entry into the list of the most developed countries in the world.

\section{REFERENCES:}

1. Senyshyn, O.S., Horyn, M.O. (2014). Derzhavne rehuliuvannia ekonomiky [State regulation of Economy]. Lviv: LNU named after I. Franko, 334 p. (in Ukrainian)

2. Khvostina I., Semerikov S., Yatsiuk O., Daliak N., Romanko O., Shmeltser E. (2020). Casual analysis of financial and operational risks of oil and gas companies in condition of emergent economy. CEUR Workshop Proceedings, vol. 2713, pp. 41-52. Available at: http://ceur-ws.org/Vol-2713/ (accessed 5 November 2020).

3. Malynovska G., Kis S., Kalambet Ya., Yatsiuk O. (2020). A mathematical and testing tool for personal human capital research assessment. Management Science Letters, vol. 10, iss. 14, pp. 3291-3298. DOI: $10.5267 / \mathrm{j} . \mathrm{msl} .2020 .6 .009$

4. Kis S., Mosora L. Mosora Yu., Yatsiuk O., Malynovska G., Pobihun S. (2020). Personnel Certification as a Necessary Condition for Enterprise' Staff Development. Management Systems in Production Engineering, vol. 28, issue 2, pp. 121-126. DOI: 10.2478/mspe-2020-0018

5. Kis S., Malynovska G., Petrenko V., Yatsiuk O. (2019). Matrix of Personality Intelligent Characteristics as an Instrument for its Development Management, Advances in Economics, Business and Management Research, vol. 95. DOI: 10.2991/smtesm-19.2019.64

6. Tymchenko K., Piddubnyi I. (2003). Chy peretvorytsia Ukraina na tekhnolohichnoho autsaidera? [Will Ukraine become a technological outsider?]. Synerhiia, no. 1(5), pp. 64-68. (in Ukrainian)

7. Halchynskyi A. (2003). V ukrainskomu politykumi - defitsyt nosiiv ne spozhyvatskoi, a investytsiinoi modeli rozvytku [In the Ukrainian politicum - a shortage of carriers of not consumer but investment model of development]. Den, no. 224, p. 2. (in Ukrainian)

8. Hladkov Y.S. (2003). Zarubezhnyi opyt krizisnoho upravlenyia (na primere Respubliki Koreia) [Foreign experience of crisis management (on the example of the Korea Republic)]. Hosudarstvennoe upravlenye. Elektronnyi vestnyk, no. 1. Available at: https://cyberleninka.ru/article/n/zarubezhnyy-opyt-krizisnogo-upravleniya-na-primere-respublikikoreya (accessed 5 November 2020). (in Russian)

9. Syroezhkin K. (2000). Chebol - kak simvol ekonomiki Yuzhnoi Korei [Chebol as a symbol of the South Korean economy]. Kontynent, no. 13(26), pp. 2-5. (in Russian) 
10. The Maeil Business News Korea paper (2000). Seoul. January 10. Available at: https://pulsenews.co.kr/ ? ga=2.219069905.915251909.1604570101-86693436 3.1604570101 (accessed 5 November 2020).

11.Predborskyi V.A. (2005). Detinizatsiia ekonomiky v konteksti transformatsiinykh protsesiv [De-shadowing of the economy in the context of transformation processes]. Pytannia teorii ta metodolohii. Kyiv: Kondor, 614 p.

12. Macmillan C. (1988). Japanese industrial system. Cleveland, pp. 49-57.

13. Haluk I. (2015). Rozwój wiedzy jako przesłanka dojrzałości innowacyjnej systemu organizacyjnego. Zeszyty naukowe Politechniki Poznańskiej, vol. 64, pp. 65-72.

14. Okuno-Fujiwara M., Suzumura K. (1985). Economic Analisis of industrial Polisy: A Conceptual Framework through the Japanese Experience. Tokyo, p. 31.

\section{БІБЛІОГРАФІЧНИЙ СПИСОК:}

1. Сенишин О.С., Горин М.О. (2014). Державне регулювання економіки. Львів : ЛНУ імені І. Франка, $334 \mathrm{p.}$

2. Khvostina I., Semerikov S., Yatsiuk O., Daliak N., Romanko O., Shmeltser E. (2020). Casual analysis of financial and operational risks of oil and gas companies in condition of emergent economy. CEUR Workshop Proceedings, vol. 2713, pp. 41-52. Available at: http://ceur-ws.org/Vol-2713/(датазвернення: 05.11.2020).

3. Malynovska G., Kis S., Kalambet Ya., Yatsiuk O. (2020). A mathematical and testing tool for personal human capital research assessment. Management Science Letters, vol. 10, iss. 14, pp. 3291-3298. DOI: 10.5267/j.msl.2020.6.009

4. Kis S., Mosora L. Mosora Yu., Yatsiuk O., Malynovska G., Pobihun S. (2020). Personnel Certification as a Necessary Condition for Enterprise'
Staff Development. Management Systems in Production Engineering, vol. 28, issue 2, pp. 121-126. DOI: 10.2478/ mspe-2020-0018

5. Kis S., Malynovska G., Petrenko V., Yatsiuk O. (2019). Matrix of Personality Intelligent Characteristics as an Instrument for its Development Management. Advances in Economics, Business and Management Research, vol. 95. DOI: 10.2991/smtesm-19.2019.64

6. Тимченко К., Піддубний І. (2003). Чи перетвориться Україна на технологічного аутсайдера? Синергія. № 1(5). С. 64-68.

7. Гальчинський А. (2003). В українському політикумі - дефіцит носіїв не споживацької, а інвестиційної моделі розвитку. День. № 224. С. 2.

8. Гладков И.С. (2003). Зарубежный опыт кризисного управления (на примере Республики Корея). Государственное управление. Электронный вестник. № 1. Режим доступу: https://cyberleninka.ru/article/n/ zarubezhnyy-opyt-krizisnogo-upravleniya-na-primererespubliki-koreya (дата звернення: 05.11.2020).

9. Сыроежкин К. (2000). Чебол - как символ экономики Южной Кореи. Континент. № 13(26). С. 2-5.

10.The Mail Business Newspaper (2000). Seoul. January10.Availableat:http://www.spa.msu.ru/e-journal/ 1/15 1.php (дата звернення: 05.11.2020).

11. Предборський В.А. (2005). Детінізація економіки в контексті трансформаційних процесів. Питання теорії та методології. Київ : Кондор, 614 с.

12. Macmillan C. (1988). Japanese industrial system. Cleveland, pp. 49-57.

13. Haluk I. (2015). Rozwój wiedzy jako przesłanka dojrzałości innowacyjnej systemu organizacyjnego. Zeszyty naukowe Politechniki Poznańskiej, vol. 64, pp. 65-72.

14. Okuno-Fujiwara M., Suzumura K. (1985). Economic Analisis of industrial Polisy: A Conceptual Framework through the Japanese Experience. Tokyo, p. 31. 